\title{
Application of Personal Information Cash Flow (APIC) - Based Financial Practice Innovation as a Pillar of Financial Education
}

\author{
SUNITHA DEVI* \\ PUTU EKA DIANITA MAR VILIANTI DE WI \\ LUCY SRI MUSMINI \\ Universitas Pendidikan Ganesha
}

\begin{abstract}
This research was conducted to prove that APIC-based financial learning practices can improve financial literacy, which also has a positive effect on inclusive financial management education. The grand theory used in this research is Behavioral Finance Theory. The sample of this research used an error rate of 5\%; therefore, the sample obtained amounted to 347 people. This study used the design of $R \& D$ and also the design of media applications. The study was conducted using a mixed-method. Data analysis techniques used: 1) data eligibility test, 2) t-test through one-way ANOVA analysis and 3) simple regression. The results showed that: (a) the APIC work system that was developed had met the material and media validity requirements, (b) APICbased financial learning practices were able to increase financial literacy, and (c) APIC-based financial literacy had a positive effect on the level of inclusive financial management.
\end{abstract}

Keywords: APIC, Financial Literacy, Financial Inclusive

Abstrak: Penelitian ini dilakukan dengan tujuan untuk membuktikan bahwa praktik pembelajaran keuangan berbasis APIC mampu meningkatkan literasi keuangan yang pada akhirnya juga berpengaruh positif pada edukasi pengelolaan keuangan inklusif. Grand theory yang digunakan dalam penelitian ini adalah Behavioral Finance Theory. Sampel dalam penelitian ini menggunakan tingkat kesalahan sebesar 5\%, sehingga sampel yang diperoleh berjumlah 347 orang. Penelitian ini menggunakan desain $R \& D$ dan juga desain aplikasi media. Penelitian dilakukan dengan metode campuran. Teknik analisis data yang digunakan: 1) uji kelayakan data, 2) uji t melalui analisis one-way anova, dan 3) regresi sederhana. Hasil penelitian menunjukkan bahwa: (a) sistem kerja APIC yang dikembangkan telah memenuhi persyaratan validitas materi dan media, (b) praktik pembelajaran keuangan berbasis APIC mampu meningkatkan literasi keuangan, dan (c) literasi keuangan berbasis APIC telah berpengaruh positif pada tingkat pengelolaan keuangan inklusif.

Kata Kunci: APIC, Literasi Keuangan, Inklusi Keuangan

\footnotetext{
* Corresponding author: sunitha.devi@undiksha.ac.id
} 


\section{Introduction}

The Indonesian government focuses on increasing financial inclusion until 2020 because financial inclusion is believed to bring prosperity to the community (Yanti, 2019). Financial inclusion is also a national strategy to reduce poverty so that the economy grows (Yanti, 2019). According to Abubakar dan Handayani (2019), financial inclusion can be interpreted as a process of leveling the opportunity and participation of the community, especially for people who are classified as unbanked to be able to access finance. Financial inclusion in Indonesia has not been able to touch all groups of people, as evidenced by research results Nugroho dan Purwanti (2017), who found that the participation of young people in using the facilities of formal financial institutions was low. Nugroho and Purwanti's research (2017), conducted in Indonesia with a sample of 1,000 respondents from the Indonesian population taken from the World Bank Gallup World Poll Survey 2014, shows that individuals over 24 years of age (working period) have a more significant percentage in account ownership, saving and borrowing activities compared to someone who has an age range of 15-24 years (school period). This reflects that several groups have not been able to enjoy access to finance.

One of the causes of the low participation of young people (generations $\mathrm{Y}$ and $\mathrm{Z}$ ) in using formal financial institution facilities is because they are still students who, of course, do not have jobs and do not have income when compared to those aged over 24 years (Nugroho dan Purwanti, 2017). The high administrative costs of banks are also the cause of the lack of desire of the younger generation to save funds in banks or other financial institutions. To overcome these problems, the Indonesian government has programmed financial products or services that can be utilized by generation $\mathrm{X}$ (generations born in 1965-1980). The government has also provided financial products or services that can be utilized by students (generation $\mathrm{Z}$ who were born around 19952010), such as the "Tabunganku" program, which is free of administration fees. However, these products have not been utilized optimally by generations $\mathrm{Y}$ and $\mathrm{Z}$, also known as the millennial generation and the internet generation.

The low level of the financial inclusion index of the younger generation (millennials and internet), especially on the probability dimension of account ownership 
with a percentage of $36.18 \%$ and the probability of saving in a financial institution with a percentage of only $24.34 \%$, can be seen in Figure 1 . The low level of financial inclusion index in the younger generation is due to the lack of knowledge about finance by people who have a young age on the functions of financial institutions (Nugroho dan Purwanti, 2017). Financial inclusion targets and targets will not be achieved optimally if the public is not aware of the importance of financial governance due to public misunderstanding regarding finance. Financial learning model innovation is very much needed to help improve financial understanding (financial literacy), especially among the millennial generation and the internet that is adapted to the characteristics of that generation, so that the process towards financial literacy runs effectively.

Figure 1.

Financial Inclusion Rate by Age in Indonesia

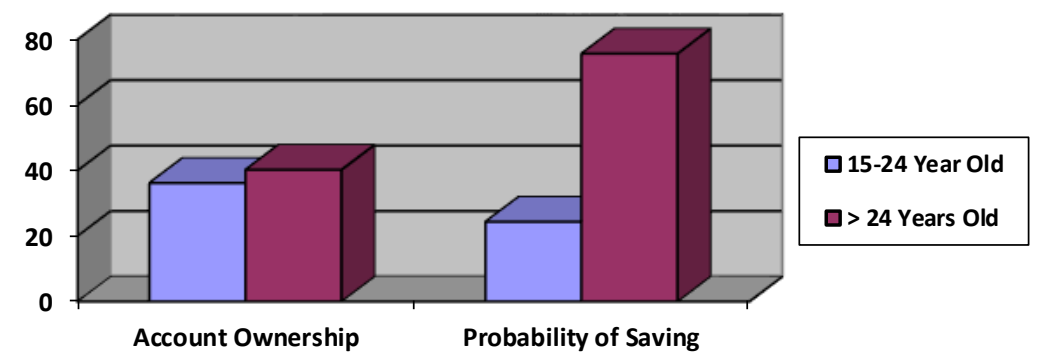

Source: Data processed (Nugroho dan Purwanti, 2017)

The millennial generation and the internet have characteristics as a generation that is close to technology. This generation has been acquainted with technology and has been familiar with the sophistication of gadgets since childhood, so whatever activities this generation does, most of them have something to do with technology. The millennial generation or the internet generation is a multi-tasking generation because this generation can carry out various activities at the same time, such as using social media via cellphones, listening to music using a headset, browsing using cellphones or PCs, and even while using cellphone applications for help with daily activities such as buying food using the GoFood application (Putra, 2016). Until 2020 today, not only generations $\mathrm{Y}$ and $\mathrm{Z}$ are very dependent on technology, but the previous generation, namely Generation X, is also very dependent on technology (Putra, 2016). 
Correspondence activities in the work environment that are e-office sent through the WhatsApp application are a form of community dependence on technology.

Children starting at the age of approximately three years have started to get to know gadgets and play with gadgets almost every day in the current digital era, and this is a phenomenon that is very difficult to avoid. If it is not directed properly, the Indonesian golden generation will not receive a positive impact from gadgets. However, it will lead to the degradation of intellectual intelligence due to the decreased enthusiasm for learning among the younger generation. The existence of developing technology becomes a threat to children if it is not used correctly and unwisely. Many students abuse technology in this digital era, and some are already addicted to online games. Based on the results of observations made by Tafonao (2019) of ten children in Banyumas who are addicted to playing online games, it was found that the ten children had been diagnosed with mental disorders. According to Hilma Paramita, a mental specialist at the Banyumas Hospital, the average patient can no longer exercise selfcontrol in playing online games, which causes the patient not to carry out everyday activities. These children are still students, and 7 out of 10 are elementary and junior high school students (Tafonao, 2019).

In addition to cases of addiction to playing online games, there are deviant behaviors that often occur among millennial students or the internet generation, such as the case of students spreading pornographic photos or videos through social media and stealing or robbing (Yuniati, 2017). Deviant behavior among millennial students or the internet generation has become a problem that can be taken seriously which should be handled immediately by various parties, including teachers in schools. Juvenile delinquency can be said as a source of social problems that require attention by all parties because it can have a negative impact on social life and the future progress of the nation (Asri, 2018).

In the financial sector, the digital era impacts a shift in the consumption pattern of most people in Indonesia, especially among the millennial generation. All necessities such as study materials, clothes, accessories, and complementary items can be easily obtained. The Nielsen Global Survey of E-Commerce conducted a study on the Internet 
generation's shift in shopping behavior. This research was conducted on 30,000 samples that have adequate access to the internet. These respondents come from 60 countries covering Asia Pacific, Latin, and North America, Europe, and the Middle East. The Nielsen Global Survey of E-Commerce provides an overview of the behavior of this generation who are familiar with the internet, choosing the internet to purchase various products or services to fulfill their daily needs (Kementerian Komunikasi dan Informatika Republik Indonesia, 2016). The ease of transacting using technology must be balanced with the millennial generation's knowledge and understanding of financial manage ment because overly consumptive behavior is also one of the causes of a decline in welfare that will lead to immoral actions such as theft.

Consumptive behavior can be interpreted as behavior that arises from a desire to purchase an item that is usually not needed. This behavior is carried out only for personal satisfaction. Humans tend to consume indefinitely, buying excessive or not having plans to buy them (Yuliana, 2019). Compulsive buying disorder is known in psychology, where it is experienced by someone who is trapped and unable to make a difference between needs and wants. This behavior does not have a basic need but desires and desires that drive it. Today, consumer behavior has undergone a shift. The orientation is no longer on activities to meet needs but rather on sensations, fulfilling joy, social life, and activities to minimize stress. This behavior is motivated by emotional features, which are carried out to get recognition by doing things not based on realistic thinking. This behavior can lead to waste. The statement that consumer behavior today is more directed towards sensation, fulfillment of joy and recognition, is in line with a study from Yuliani (2019). The results of the Yuliani study (2019) explain that consumptive actions produce negative impacts, namely waste, giving rise to showing off, and creating behaviors that are considered harmful for the surrounding environment. The Indonesian people, especially the Indonesian millennial generation, are also very fond of imported and branded goods, which causes Indonesia to become one of the main target markets for companies abroad to maximize profits. The wise attitude of the millennial generation, which is used in personal financial management, 
is closely related to their ability, knowledge, and understanding of financial planning, which is often referred to by another name, namely financial literacy.

Financial literacy can be interpreted as an ability to understand money or finance or apply the knowledge possessed in making effective financial decisions (Coskuner, 2016). Financial literacy is a level of knowledge, skills, and confidence that influences attitudes and behavior to improve the quality of decision-making and manage finances to prosper the community (Otoritas Jasa Keuangan, 2018). The 2013 National Financial Literacy Survey conducted by OJK describes the state of financial literacy in Indonesia. The index of financial literacy in society in Indonesia is only around $21.8 \%$, meaning that out of 100 residents, only 22 people are in the category well literate. These results show that people in Indonesia do not all understand how to optimize money for productive activities. Although in 2016 the increase in the financial literacy index showed the number to $29.7 \%$, and in 2019 it increased to $38.03 \%$, the value of the financial literacy index is still below 50\%, which means that people in Indonesia are not categorized as having adequate knowledge and understanding enough about how to maximize money for something productive (Otoritas Jasa Keuangan, 2018).

Financial education is believed to influence individual awareness of financial manage ment (Otoritas Jasa Keuangan, 2018). One of the many roles of education in this digitalization era to improve financial literacy where all information can be obtained easily through technological facilities is by creating technology-based learning innovations. From the past, learning has only depended on literature books that no longer follow the millennial generation's character and needs. Technological advances will positively impact the younger generation only if the technology is used and possible to visit literacy sources for learning materials other than the learning obtained from teachers in schools. One of the efforts that can be done is to create unique learning modules and create interesting electronic applications that can be accessed via smartphones or PCs so that the millennial generation can practice the theory that has been read in the module. Through the use of technology in the learning process, millennials can learn any where and anytime. The technology-based learning innovation is expected to help increase financial literacy among the millennial generation and 
improve financial inclusion management. The higher the level of financial literacy will have implications for the high level of use or inclusion of financial products (Cardinal, 2017).

Refers to several previous research results that prove the importance of using technology appropriately by the millennial generation to avoid actions immoral or consumptive behavior, causing researchers to be motivated to carry out development research on innovation-based financial literacy practices, personal e-budgeting, and cash flow which is presented in the form of APIC (Application of Personal Information Cash Flow) as a pillar of inclusive financial education among the millennial generation. The APIC system is a technology-based financial learning media. There are financial learning modules and media for the application of e-budgeting and cash flow with exciting features. So far, the e-budgeting and cash flow system is more aimed at organizations. Therefore, research on the development of a personal financial management system in APIC is essential to realize financial literacy for all levels of society independently.

The APIC application, which accommodates e-budgeting and cash flow until the formation of recording and reporting on the use of funds, is also an effort to guide human behavior in responding to information generated in an integrated accounting system. The accounting system has a broad meaning, namely the entire design, including control systems, budgeting systems, cost collection designs, and financial reporting designs. In the APIC system, an integrated accounting system pattern is created starting from budgeting costs and revenues, recording the realization of expenses or costs and income, to producing reports on expenses and income for a certain period and the remaining funding held. The APIC application is also integrated with investment options that can be utilized when the user has remaining funding. The existence of an integrated accounting system through the APIC application is undoubtedly beneficial for users in obtaining information that can be used for the financial control process. Applicative learning related to a sound financial control system through the APIC application is expected to free the millennial generation from consumptive behavior effectively. This concept is a development idea in the scope of behavioral accounting that focuses on 
how the accounting system can affect a person's motivation, productivity, and decisionmaking related to his finances (Septiarini, 2013).

The research questions that will be investigated are: (1) whether the developed APIC work system has met the requirements for the validity of materials and media, 2) whether APIC-based financial learning practices can improve financial literacy, and (2) whether APIC-based financial literacy has an effect on management inclusive finance. This research using Research and Development $(R \& D)$ designs to develop and validate media to answer question number one; this research is also designed for media applications to answer questions number two and three. Tests related to media validation are carried out using a mixed-method, namely, by implementing a combination of quantitative and qualitative approaches. Meanwhile, testing related to the effect of media application on financial literacy, which ultimately impacts financial inclusion, is carried out using quantitative methods. The benefit of this research is the validation of digital-based learning media that can help increase financial understanding among the millennial generation while helping to achieve increased financial inclusion.

\section{Theoretical Framework and Hypothesis}

\subsection{Behavioral Finance Theory}

This research uses behavioral finance theory as a grand theory. Behavioral finance theory is a theory about the psychological impact on the behavior of financial actors, which in turn affects the use of financial instruments (Alquraan et al., 2016). Menurut Pradikasari dan Isbanah (2018), Behavioral finance, explains how big the model of financial phenomena can be understood by someone who will influence the final investment decision following considering the return and risk. Behavioral finance involves factors like preferences, traits, emotions, and everything in humans as creatures of God who are intellectual and social, which decides to take a stance in the financial sector. (Sukandani et al., 2019). Indicators that can be used to measure behavioral finance including the existence of bills paid on time (e.g., electricity payments and postpaid credit), making budgets for spending and expenses (from daily, monthly, and other expenses), recording expenditures and expenses, preparing funds for emergencies 
(emergency fund), save regularly, and also conduct a price comparison between stores and supermarkets before making a purchase decision.

\subsection{Behavioral Accounting}

Behavioral accounting is a branch of accounting that studies the relationship between human behavior and the accounting system (Siegel, G. et al., 1989). The accounting system has a broad meaning: the entire design of management control tools, including control systems, budgeting systems, accountability accounting designs, organizational designs such as decentralization or centralization, cost collection designs, performance appraisal designs, and financial reporting. The scope of behavioral accounting includes: 1) studying the effect of the accounting system on human behavior, which means how the accounting system affects motivation, productivity, decision making, job satisfaction, and cooperation; 2) studying the effect of human behavior on the design, construction, and use of accounting systems applied in companies, which means how management attitudes and leadership styles affect the nature of accounting controls and organizational design; 3) methods to predict human behavior and strategies to change it, which means how the accounting system can be used to influence behavior (Septiarini, 2013).

\subsection{Financial Literacy}

Financial literacy is cognitive knowledge and mathematical abilities about personal finance used as the basis for taking financial steps, with a fixed point of view on the very best near-term and long-term thinking (Awais et al., 2016). According to (Coskuner, 2016), financial literacy is a skill in understanding money and finance and being able and confident in applying this knowledge to make the right decisions in the financial sector because the core skills needed today are making sound financial decisions. Meanwhile, according to the Financial Services Authority (2018), financial literacy is the level of knowledge, skills, and confidence that influences the attitude and behavior to improve financial management and the quality of financial decision-making to achieve prosperity. The hope is that the public will not only understand a financial institution and existing financial products and services but will be able to provide 
changes to the community in managing finances so that their welfare will increase (Financial Services Authority, 2018).

According to the Financial Services Authority (OJK), financial literacy objectives are a) to increase the literacy rate of individuals who were initially less literate or not literate to become well literate, and b) to increase the number of people using financial services products. How many individuals at a good level of financial literacy have expertise in deciding what financial products and services they need, fully understand the risks and benefits, understand their obligations and rights, and are sure of what has been decided in the use of a financial service and product that will be used in the future can improve the welfare of the users themselves (Financial Services Authority, 2017).

\subsection{Financial inclusion}

Financial inclusion is composed of two main words: inclusion, which means to enter, and finance, which generally means things related to money. According to Abubakar dan Handayani (2019), Financial inclusion increases the existence of opportunities and community participation, especially for the unbanked community. Bank Indonesia has an inclusive financial plan that is already connected to technology in the financial sector. In the future, it is hoped that it will impact increasing public access to finance and banking (Bank Indonesia, 2019). Financial inclusion assists underserved communities in increasing their productivity and income, which will later become a critical factor in poverty alleviation. Financial inclusion gives a person the opportunity to open savings and make loans for business and family needs. In the national financial inclusion plan, the preparation of inclusive finance consists of five pillars, namely education in the financial sector, community property rights, financial services in the government sector, consumer protection, and an intermediation facility. (Septiyani, 2019). Financial education is a policy plan to increase expertise in financial management from the start by providing an increase in perspective (knowledge) and awareness of the whole community about financial products and services. Existing areas of financial education include a) understanding and awareness of various types of financial products and services; $b$ ) there is an understanding and awareness of the risks 
of the existence of financial products; and c) providing protection to customers (Septiyani, 2019).

\subsection{Millennial and Internet Generation}

Generations $\mathrm{X}, \mathrm{Y}$, and $\mathrm{Z}$ are the generations introduced based on the theory of generations. At the end of World War II, five generations were born, namely Baby Boomers (born in 1946-1964), Generation X (born in 1965-1980), then Generation Y (born in 1981 - 1994), for Generation Z (born in 1995). -2010), and Alpha generation (born in 2011-2025) (Bencsik et al., 2016). Generations Y and Z, or the digital generation, are young people who grow and develop depending on digital technology. Generations $\mathrm{Y}$ and $\mathrm{Z}$ were born when technology already existed, making this generation a character who likes technology, is flexible, has more intelligence, and is highly tolerant of cultural differences. This generation is connected worldwide and has a network in cyberspace; and also likes to communicate with all kinds of groups by utilizing existing social networks, namely Facebook, Twitter, and Messenger. Even so, this generation is a generation that has a hobby of instant culture and lacks a private nature, and tends to indulge in social media life. Generations $\mathrm{Y}$ and $\mathrm{Z}$ can access information quickly even though they are still relatively young. This generation tends to be tolerant of cultural differences and care deeply about the environment. Generations $\mathrm{Y}$ and $\mathrm{Z}$ can be familiar with various types of activities at the same time.

Generations $\mathrm{Y}$ and $\mathrm{Z}$ or the digital generation are individuals who are very adept at mastering information technology. All the information needed is straightforward to obtain for everyday or educational purposes. Through technological devices called millennials, they can become efficient and more productive individuals. Through technology devices, millennials can also carry out activities ranging from sending messages, visiting educational sites, opening businesses online to ordering online transportation services. Therefore, they are very capable of forming real and new opportunities as technological developments are increasingly sophisticated. Research results from the Boston Consulting Group (BCG), the University of Berkley in 2011 regarding the millennial generation in the USA, explained that the interest in reading 
conventionally has decreased because the millennial generation has switched to using technology or even their smartphones in obtaining information.

\section{6. e-Budgeting and Cash Flow}

According to Zakiyah et al. (2020), A budget is a financial plan, usually including short-term planning used for control. In comparison, e-Budgeting is an information system used in preparing budgets to provide increased efficiency and effectiveness in the budgeting process. This system can reduce the time needed in a budget planning process because it is carried out online and viewed in various places. This system has another function, namely as a tool for work supervision. The e-Budgeting system is a web-based budget planning system to facilitate preparing income (income planning) and cash disbursements.

The cash disbursements and receipts process is then reported into a report, namely a cash flow report. Content of PSAK No.2 (2015), Cash flow is the outflow and inflow of cash and cash equivalents. The cash flow statement must contain clear and precise information so that the cash flow statement indeed describes the real cash inflows and outputs that occur in the company (Noor, dan Kamaludin, 2019). For companies, cash flow statements are one tool used to measure company performance (cash flow). In simple terms, financial performance is categorized as good if there is a surplus (more significant cash inflows than cash outflows) for the category of daily operational activities (Sitohang et al., 2019). The e-Cash Flow system means a system for recording cash outflows and cash inflows in real terms with the help of technology. The media for the application of e-budgeting and personal cash flow was then developed into the Application of Personal Information Cash Flow (APIC) system model. APIC is a technology-based application system that can produce planning information and realize cash inflows and cash flow out of personal finance. There are also innovative financial learning modules.

\subsection{Hypothesis Development}

In developing a technology-based system that will support the learning process, it must be tested in terms of materials, media and tested from the user side Krismasari (2016). The developed APIC system contains all the components required by a system 
that is categorized as valid. Users can access the module in the form of animated videos adapted to the development of students. Applications for carrying out financial practices in the form of budgeting and recording cash flows have been adapted to students' daily lives, and the appearance of the system has also been adapted to the content of learning content. The APIC working system developed has attempted to meet the requirements for the validity of materials and media. It is hoped that this APIC-based financial practice innovation can be tested for validity.

APIC is designed according to the character of the millennial generation and the internet. The millennial generation and the internet have elements of character who like technology, are flexible, are more intelligent, and are tolerant of cultural differences. This generation, at a very young age, has extraordinary skills in accessing information quickly. One of the findings from research conducted by the Boston Consulting Group (BCG), the University of Berkley in 2011 regarding the USA millennial generation, namely the interest in reading conventionally, is now experiencing a decline because the millennial generation prefers to read through technology or even their smartphones. This finding is also supported by the results of a study conducted by Putri et al. (2019) and research by Wuryanti and Kartowagiran (2016), which stated that students showed more interest in understanding microeconomic theory by using web-based teaching materials compared to conventional teaching materials. Teaching materials in the form of modules that have been adapted to follow students' character greatly help increase students' willingness to learn independently, can help overcome student learning difficulties, which in turn has an impact on increasing student understanding. Putri et. al.[ (2019) found that interest in understanding microeconomics theory through webbased teaching materials significantly impacts increasing financial literacy among students. Therefore, APIC is rightly developed to help improve financial literacy. The formulation of a hypothesis refers to the explanation, namely:

H1: APIC-based financial learning practices can improve financial literacy.

In the national financial inclusion plan, the financial inclusion program is divided into five pillars: providing financial understanding, property rights of the community, 
financial services in the government sector, consumer protection, and intermediation and distribution facilities. (Septiyani, 2019). Financial education is a policy design to increase capacity in financial management, which begins with increasing knowledge and awareness of the public about a financial product and service. The scope of education in the financial sector consists of a) An understanding and awareness of the types of financial products and services; b) understanding and awareness of the risks of financial products; c) customers are given protection. The fact is that even though access to finance is very open, it may not necessarily increase the financial inclusion index because the critical factor remains in the community, whether or not giving the decision to use the available financial products or services. This fact follows behavioral finance theory, which states that the factors of nature, emotions, preferences and various other things in humans as intellectual and social beings will later underlie the decision to act in the financial sector. (Sukandani et al., 2019). Indicators measuring behavioral finance include recording all expenses and expenditures, allocating and preparing funds for sudden events (emergency funds), and saving periodically.

Productive financial decision-making can only be realized if the community has a good financial understanding (financial literacy). (Coskuner, 2016). Financial education through APIC which is designed based on technology following the passions of the younger generation to increase interest in learning financial governance of the younger generation and which is synergized with designs according to indicators to encourage the achievement of behavioral finance, as well as designs that are integrated with the choice of financial product services are strategies to provide improved understanding and awareness in the community regarding financial products and services. People who already understand and are well educated will automatically use banking services in their daily lives. However, if it is the other way around, it will not be able to maximize financial inclusion (Sohilauw, 2018). Taking temporary answers that refer to the explanation, namely:

H2: APIC-based financial literacy has a positive effect on inclusive financial management education. 


\section{Research Method}

In addition to using Research and Development (R\&D) designs to develop and validate media, this research is also designed for media applications. Tests related to media validation are carried out using a mixed-method, namely, by implementing a combination of quantitative and qualitative approaches. According to Syahroh et al. (2019), the mixed methods method uses a research strategy that applies more than one type of research method to provide the broadest knowledge about the problem under study. The mixed-method model chosen is sequential explanatory, a combined research method that sequentially combines quantitative and qualitative methods. The first stage applies quantitative methods, and the second stage is carried out using qualitative methods. Meanwhile, testing related to the effect of media application on financial literacy, which ultimately impacts financial inclusion, is carried out using quantitative methods.

The components or instruments used to test the system in terms of material include: 1) basic skills that are following the material, 2) accurate materials, 3) up-to-date materials (according to everyday life), 4) encouraging curiosity, 5) a sequence of presentation techniques, 6) the existence of a presentation supporter, 7) the presentation of a lesson, 8) the sequence of a line of thought and coherence, 9) the use of straightforward language, 10) communicative, 11) interactive and dialogical, 12) something with the development of students, 13) following the rules of language, and 14) contextual nature. The components or instruments used to test the system in terms of media include: 1) conformity of module sizes and applications that have ISO standards, 2) appropriate module materials, 3) face-to-face display and layout, which adheres to consistency and harmonization, is also implemented in this section, 4) provide clarity of function with elements of color and harmonious layout, 5) provide ease of reading and exciting letters, 6) combination of letters that are not too many, 7) illustrations of appropriate module covers, 8) consistency of layout, 9 ) harmonization of layout elements, 10) complete layout elements, 11) page acceleration through layout, 12) simple typography of module content and applications, 13) topography of module and application content that makes it easier to understand, and 14) creative content 
illustrations. Meanwhile, from the user perspective, the components or instruments used to test the system include 1) interest, 2) material, and 3) language.

For the initial stage, the researcher will test the validity of the APIC-based learning model; after passing the validity test, the next stage is to test the application of media to assess the usefulness of APIC-based financial learning practices in improving financial literacy and their impact on improving financial inclusion management. The instrument used for testing the validity of development research is a validation questionnaire in the form of a checklist given a score using a Likert scale to evaluate the media of the developed learning. This validity test will also be supported by interviews with material experts, media, and different users. This is done to support further the results of Research and Development (R\&D). The primary data used in this study are 1) the form of system validity test results, 2) the results of the system application questionnaire, and 3) the results of interviews. Data collection in the quantitative approach was carried out by distributing questionnaires to the validators and the users. In contrast, the data collected in the qualitative approach was carried out through interviews with the validators and the users.

\subsection{Population and Sample}

The population of this research is students who are studying D3 or S1 from all regencies in Bali, totaling 148,397 people, based on the data listed in the 2019 Research, Technology and Higher Education Forlap. The sample in this study is based on a simple method that has been developed by Isaac. and Michael with an error rate of 5\%. Based on Isaac and Michael's calculation table with an error rate of 5\%, the research sample obtained was 347 students from all districts in Bali with different study programs backgrounds. The selection of sample members who will be used as research subjects is made randomly - a system application questionnaire distributed by researchers within six months.

\subsection{Research Variables}

1) In the national financial inclusion plan, the inclusive financial plan is lowered into five pillars, namely the provision of knowledge in finance, community property rights, financial services in the government sector, facilities in the field of 
intermediation and distribution, and protection for consumers. Inclusive financial education is a policy program to increase capacity when managing finances, which begins with increasing self-knowledge and public awareness about what financial products and services are (Septiyani, 2019). The indicators used to measure financial inclusion include 1) knowledge and awareness of various financial products and services and their benefits, 2) knowledge and awareness of risks related to financial products, and 3) knowledge of customer protection in terms of security and ease of transacting at financial institutions (Septiyani, 2019). Financial inclusive education is measured through 8 question items adopted from the research Septiyani (2019) and Choirunnisa (2018), adjusted to the research conducted. The questionnaire was measured using a 5-point Likert scale (strongly disagree $=1$, disagree $=2$, neutral $=3$, agree $=4$, and strongly agree $=5$ ) .

2) According to Coskuner (2016), Financial literacy can be interpreted as an ability to understand money or finance or apply the knowledge possessed in making effective financial decisions. Analysis of the increase in financial literacy in research subjects led to the pre-test and post-test scores. The test was conducted to assess the impact of using APIC on the level of financial literacy. After that, further analysis was carried out regarding the results of the financial literacy post-test, which was tested on inclusive financial education to determine the impact of increasing financial understanding on inclusive financial management. In addition, respondents were also given a questionnaire related to financial literacy, which was measured through 8 question items adopted from the study Sisputro (2017), Fatimah (2017), and Safira dan Dewi (2019). The questionnaire was measured using a 5-point Likert scale. This is done to test the comparison between the level of financial literacy and the level of managing financial inclusion that can be achieved through APIC-based learning.

\subsection{Data Analysis Technique}

Data in the form of learning media validation results will be tested using a data feasibility test by the percentage of the total score of the test indicators, which are then categorized according to Table 1. It was carried out through a One-Way ANOVA 
analysis to test the increase in financial literacy after receiving APIC-based financial learning. One-Way Anova analysis is a t-test on pre-test and post-test data. Meanwhile, the effect of financial literacy on inclusive financial management education is carried out using a simple regression model. The data were analyzed using auxiliary media, namely the Statistical Package for the Social Sciences (SPSS) version 25 program.

Table 1.

Convert Actual Score to Category for 5-Point Likert Scale

\begin{tabular}{cl}
\hline Score Interval & \multicolumn{1}{c}{ Kategori Tingkat Validitas } \\
\hline $81 \%-100 \%$ & Very valid, can be used without revision \\
$61 \%-80,9 \%$ & Quite valid, can be used but needs revision \\
$41 \%-60,9 \%$ & Not valid, it is recommended not to use because it needs a major \\
& revision \\
$21 \%-40,9 \%$ & Invalid, cannot be used \\
\hline
\end{tabular}

Source: Azizah et al., 2018

\section{Results and Discussion}

\subsection{APIC System Research and Development Results}

At the development stage, a feasibility test is used to validate the APIC-based financial learning media that has been designed. The validator contains material experts (financial lecturers), media experts (multimedia lecturers), and users (students). The material expert validator is Mrs. Trisna, who provides an average score related to the criteria for appropriateness of the content, aspects of the appropriateness of presentation, linguistic appropriateness, and aspects of a contextual assessment of 4.37 or equal $87.42 \%$. The value given by the material expert validator is in the very valid category and can be used without revision.

The media expert validator is Mrs. Ita. The first assessment assessed 61.5\%, which was in the category of "systems and modules can be used with revisions". The revision is on the system display, and the addition of "error prevention," that is, the system can prevent the input of words that are not in the right place, such as the number column can only be filled with numbers. After revision and requesting a reassessment from Mrs. Ita, the average score related to the criteria for the appropriateness of graphics with 
indicators from module size, module and application cover design, module and application content design is 408 or equal to $81.53 \%$. The value given by the media expert validator is in a very valid class and can be used without revision.

The assessment from the user, Ray, related to student response criteria with indicators of interest, material, and language, obtained an average score of 4.64 or equal to $92.86 \%$. The value given by the user is in the very valid category and can be used without revision. Referring to the results of the assessments from validators who are material experts, media experts, and users, it can be concluded that the APIC work system developed has met the material and media validity requirements, with a total score of 0.8727 or equal to $87,27 \%$. The recapitulation of the results of media and material validation from a material expert, a media expert, and users is listed in Table 2.

Table 2.

APIC System Validity Test Result Recapitulation

\begin{tabular}{|c|c|c|c|c|c|}
\hline No. & Validator & $\begin{array}{l}\text { Total } \\
\text { Score }\end{array}$ & Average score & $\begin{array}{l}\text { Percent } \\
\text { age }\end{array}$ & Category \\
\hline 1 & $\begin{array}{c}\text { Material } \\
\text { expert }\end{array}$ & 153 & 4,37 & $87,42 \%$ & Very Valid \\
\hline 2 & $\begin{array}{l}\text { Media } \\
\text { Expert }\end{array}$ & 106 & 4,08 & $81,53 \%$ & Very Valid \\
\hline 3 & User & 65 & 4,64 & $92,86 \%$ & Very Valid \\
\hline & Total rating & & & $87,27 \%$ & Very Valid \\
\hline Person & & 3 & 3 & 3 & \\
\hline
\end{tabular}

Source: Processed data, 2020

Referring to the interview results with Mr. Budi as a material expert validator, it was concluded that contextually, presentation, and content feasibility, APIC was categorized as feasible to be used as a learning media. Mr. Budi stated, "APIC is good to use for financial management learning media because apart from the learning videos in APIC, facilities are also available for users to practice theory directly related to personal financial governance, now we just have to think about how to educate users who are still categorized as students or students to discipline to use it in everyday life". The media expert validator is Mr. Agus. also stated that "if viewed from the point of 
view of overall system design, application design, video design, or tutorial module design, APIC is said to be very suitable to be used as a medium for learning, especially the learning media provided following the reality faced by the user, namely students. or students in their personal lives. "On behalf of Kahlil as a user, the student stated that "APIC is very interesting to use for studying finance because the technology design used is very easy to understand even for students who are not from economics major, and I can use it anytime and anywhere". The results of user assessments, both quantitatively and qualitatively, prove that APIC, which can be accessed online via mobile phones, can increase the millennial generation's interest in learning finance, which concerns this group's lack of discipline in using APIC can be avoided.

Based on the qualitative results through interviews with the validators, it was found that the assessment results were the same as the quantitative results of the validators even though the validators came from different agencies and different personnel. So, it can be concluded that the APIC working system developed has met the requirements for the validity of materials and media. The following is a brief description of the APIC working system (http://smartmatikacollege.com/apic), assessed by validators and students as shown in Figure 2, Figure 3, and Figure 4.

Figure 2.

APIC Initial View(Dashboard)

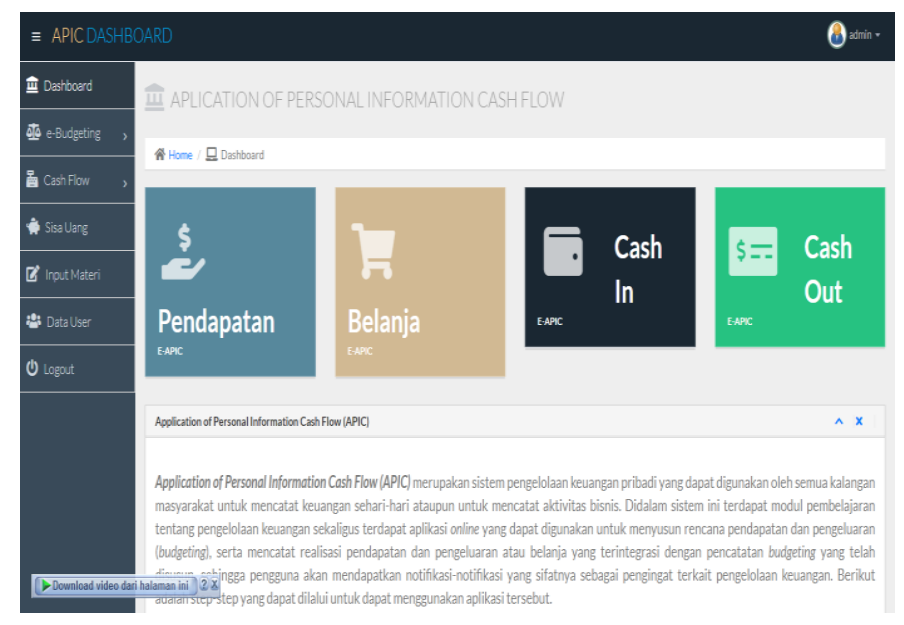


Figure 3.

APIC Usage/Operation Tutorial Display

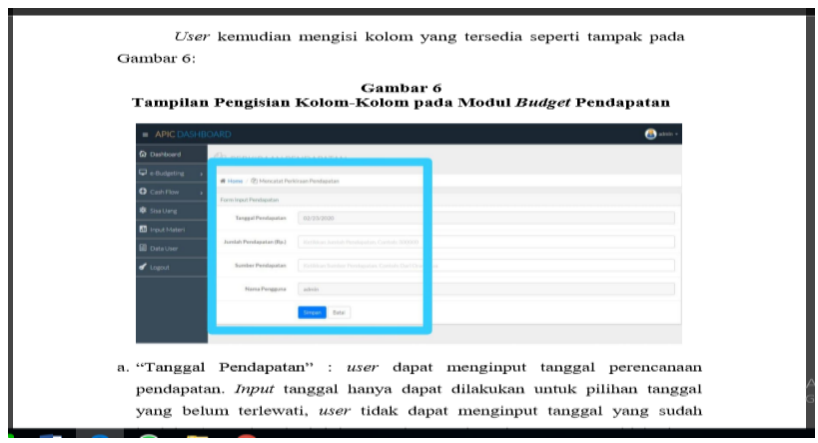

Figure 4.

Display of Learning Modules in the form of Animated Videos

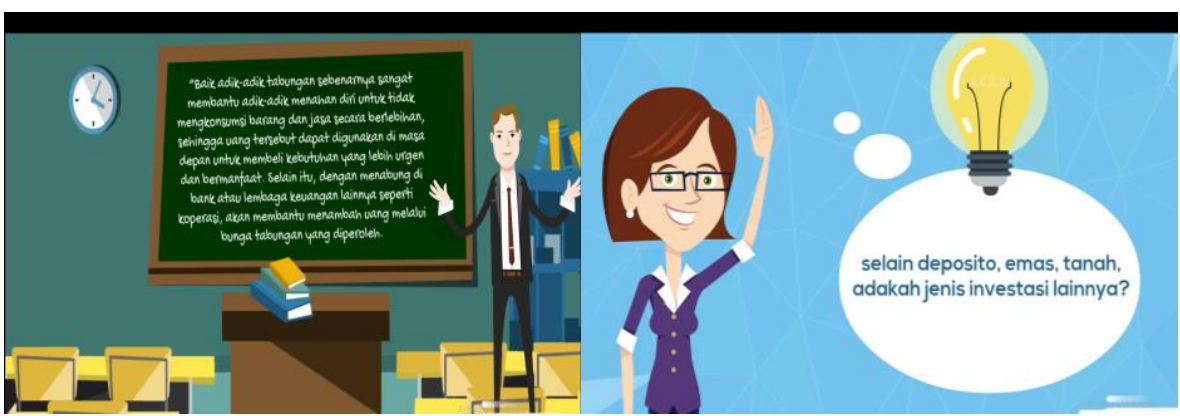

\subsection{Descriptive Analysis}

Based on the results of the descriptive analysis as shown in Table 3 and Table 4, it is known that the average value for the pre-test score is 79.38 , which is smaller than the average post-test score of 84.15. This shows an increase in test results on financial understanding (financial literacy) after receiving APIC-based financial learning. The average value of inclusion is 30.07 , smaller than the average financial literacy level of 34.85 which proves that the achievement of increasing financial inclusion is still lower than the achievement of increasing financial literacy. The maximum value for the pretest or post-test scores is the same as 100 , while the minimum value for the pre-test score is 45 and for the post-test score is 50. The research sample is 347 people, composed of 154 men and 193 women (Table 4). 
The Indonesian Journal of Accounting Research - Sept, Vol. 24, No.2 , 2021

Table 3

Descriptive Statistics

\begin{tabular}{lr|r|r|r|r}
\hline & N & Minimum & Maximum & Mean & Std. Deviation \\
\hline Literacy & 347 & 28 & 40 & 34.85 & 2.518 \\
\hline Inclusion & 347 & 23 & 35 & 30.07 & 2.499 \\
\hline Pre-test score & 347 & 45 & 100 & 79.38 & 9.646 \\
\hline Post-test score & 347 & 50 & 100 & 84.15 & 9.553 \\
\hline Valid N (listwise) & 347 & & & & \\
\hline
\end{tabular}

Source: Processed data, 2020

Table 4.

Gender Descriptive Analysis Results

\begin{tabular}{llr|r|r|r}
\hline & & & & \multicolumn{2}{c}{$\begin{array}{c}\text { Cumulative } \\
\text { Percent }\end{array}$} \\
\hline \multirow{2}{*}{ Valid } & Man & 154 & 22.2 & 44.4 & 44.4 \\
\cline { 2 - 7 } & Woman & 193 & 27.8 & 55.6 & 100.0 \\
\cline { 2 - 7 } & Total & 347 & 50.0 & 100.0 & \\
\hline \multirow{2}{*}{ Missing } & System & 347 & 50.0 & & \\
\hline Total & & 694 & 100.0 & & \\
\hline
\end{tabular}

Source: Processed Data, 2020

\subsection{Uji t (Analysis Result One-Way Anova)}

The analysis results using One-Way Anova on the average pre-test and post-test scores aimed at 347 students as a sample get the results as shown in Figure 4, Table 5, and Table 6. Based on the one-way ANOVA analysis, it was found that the research data were normally distributed through the Q-Q plot normality test (Figure 4). The entire value of Sig $>0.05$ on the Test of Homogeneity of Variances (Table 5) so that the data meets the assumption of homogeneity. The results of the one-way ANOVA analysis (Table 6) also have a sig value $<0.05$, so hypothesis 1 is supported, namely APIC-based financial learning practices can improve financial literacy. The average post-test result, which is 84.15 , is also greater than the pre-test, 79.38 (Table 3). The analysis results 
also show that there is an increase in student financial literacy after using the APIC system as a learning medium.

Figure 4.

Normality Test Results in One-Way

\section{Pre-test Group Normality}

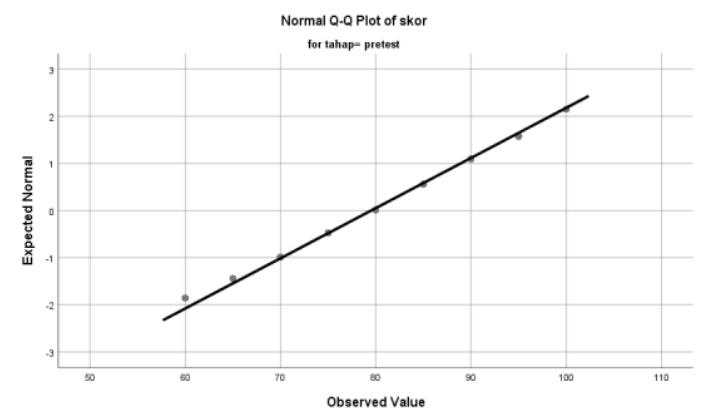

Source: Processed Data, 2020

\section{Post-Test Group Normality}

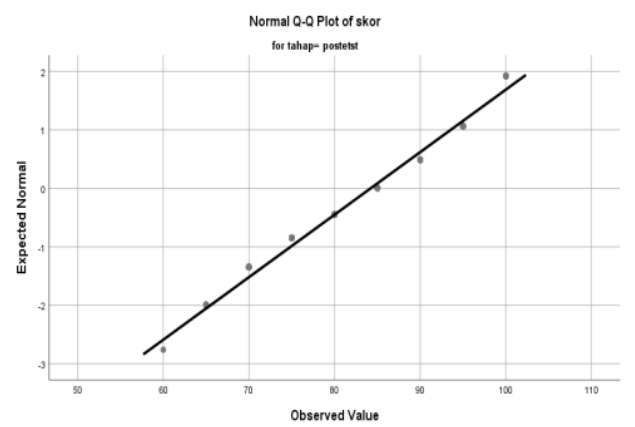

Table 5.

Test of Homogeneity of Variances

\begin{tabular}{lr|r|r|r}
\hline & Levene Statistic & df1 & \multicolumn{1}{c}{ df2 } & \multicolumn{1}{c}{ Sig. } \\
\hline Based on Mean & .457 & 1 & 692 & .499 \\
\hline Based on Median & .248 & 1 & 692 & .619 \\
\hline $\begin{array}{l}\text { Based on Median and with } \\
\text { adjusted df }\end{array}$ & .248 & 1 & 689.753 & .619 \\
\hline Based on trimmed mean & & & & \\
\hline
\end{tabular}

Source: Processed Data, 2020

Table 6.

Anova

\begin{tabular}{lr|r|r|r|r}
\hline \multicolumn{1}{l}{ score } & \multicolumn{1}{l}{ Sig. } \\
\hline Sum of Squares & \multicolumn{1}{c}{ Df } & Mean Square & \multicolumn{1}{c}{ F } & \multicolumn{1}{c}{ Sig. } \\
\hline Between Groups & 3828.386 & 1 & 3828.386 & 43.583 & .000 \\
\hline Within Groups & 60786.455 & 692 & 87.842 & & \\
\hline Total & 64614.841 & 693 & & & \\
\hline
\end{tabular}

Source: Processed Data, 2020 


\subsection{Classic Assumption Test}

The results of the classical assumption test, in general, can show that: (a) the results of the QQ plot normality test indicate that the research data can be divided normally, (2) the results of the multicollinearity test indicate if there are no symptoms of multicollinearity seen from the presence of a smaller Centered VIF value of 10, (3) the results of the Glejser test which show that there are no symptoms of heteroscedasticity seen from the probability value of the relationship of the independent variable on the absolute residual which is not significant for the value of alpha 5\% which has a significance score of 0.08 whose value is below 0,05 .

\subsection{Regression Analysis Results}

The results of the simple regression analysis are shown in Table 7, Table 8, and Table 9. The results in Table 8 can be seen if the significance value of the $F$ (simultaneous) test results is 0.00 , positioned below 0.05 , which is a predetermined level. From these results, it can be concluded that financial literacy has a significant effect on financial inclusion management. The regression model has been declared fit (feasible) so that the hypothesis proof can be continued. The Adjusted R-squared value of 0.868 (Table 7) illustrates that financial literacy can explain the level of financial inclusion management of $86.8 \%$. In comparison, the remaining $13.2 \%$ is explained by variables other than the variables in the research model.

Table 7.

Model Summary

\begin{tabular}{lr|r|r|r}
\hline TModel & $R$ & $R$ Square & \multicolumn{1}{c}{$\begin{array}{c}\text { Adjusted } R \\
\text { Square }\end{array}$} & $\begin{array}{l}\text { Std. Error of the } \\
\text { Estimate }\end{array}$ \\
\hline 1 & $.932^{\mathrm{a}}$ & .869 & .868 & .905 \\
\hline
\end{tabular}

a. Predictors: (Constant), Literasi

Source: Processed Data, 2020

Financial literacy has a significance score on the regression test results of $0.00<$ 0.05 (Table 9). The test results show that if hypothesis 2 is accepted, that is, financial literacy impacts the level of financial inclusion management. The value of the financial literacy regression coefficient is as positive as much as 0.925 , which means that 
financial literacy positively impacts the level of financial inclusion management. The higher the level of financial literacy in each individual, the higher the management in inclusive finance that that person will carry out.

Table 8.

Anova

\begin{tabular}{|c|c|c|c|c|c|c|}
\hline \multicolumn{2}{|c|}{ Model } & \multirow{2}{*}{$\begin{array}{l}\begin{array}{l}\text { Sum of } \\
\text { Squares }\end{array} \\
1877.809\end{array}$} & \multirow{2}{*}{$\begin{array}{l}D f \\
1\end{array}$} & \multirow{2}{*}{$\begin{array}{l}\text { Mean } \\
\text { Square } \\
1877.809\end{array}$} & \multirow{2}{*}{$\frac{F}{2292.998}$} & \multirow{2}{*}{$\frac{\text { Sig. }}{.000^{\mathrm{b}}}$} \\
\hline 1 & Regression & & & & & \\
\hline & Residual & 282.531 & 345 & .819 & & \\
\hline & Total & 2160.340 & 346 & & & \\
\hline
\end{tabular}

a. Dependent Variable: Inklusi

b. Predictors: (Constant), Literasi

Source: Processed data, 2020

Table 9.

Coefficients

\begin{tabular}{|c|c|c|c|c|c|c|}
\hline \multirow{2}{*}{\multicolumn{2}{|c|}{ Model }} & \multicolumn{2}{|c|}{$\begin{array}{c}\text { Unstandardized } \\
\text { Coefficients }\end{array}$} & \multirow{2}{*}{$\begin{array}{c}\text { Standardized } \\
\text { Coefficients } \\
\text { Beta }\end{array}$} & \multirow[b]{2}{*}{$T$} & \multirow[b]{2}{*}{ Sig. } \\
\hline & & $B$ & Std. Error & & & \\
\hline \multirow[t]{2}{*}{1} & (Constant) & -2.178 & .675 & & -3.226 & .001 \\
\hline & Literacy & .925 & .019 & .932 & 47.885 & .000 \\
\hline
\end{tabular}

a. Dependent Variable: Inklusi

Source: Processed Data, 2020

\subsection{Comparison of Inclusive Financial Management Levels between Men and Women}

In this study, an additional analysis was conducted to assess the differences in financial inclusion management between men and women. The analysis results show that the level of financial inclusion of women is higher than the level of financial inclusion of men; as shown in Table 10, the average value of financial inclusion for men is 28.97 while for women 30.94 . 
Table 10.

Descriptives

Inclusion

\begin{tabular}{|c|c|c|c|c|c|c|c|c|}
\hline & \multirow[b]{2}{*}{$\mathrm{N}$} & \multirow[b]{2}{*}{$\begin{array}{c}M e a \\
n\end{array}$} & \multirow{2}{*}{$\begin{array}{c}\text { Std. } \\
\text { Deviati } \\
\text { on }\end{array}$} & \multirow{2}{*}{$\begin{array}{l}\text { Std. } \\
\text { Erro } \\
\quad r\end{array}$} & \multicolumn{2}{|c|}{$\begin{array}{l}95 \% \text { Confidence Interval } \\
\text { for Mean }\end{array}$} & \multirow[b]{2}{*}{$\begin{array}{l}\text { Minimu } \\
m\end{array}$} & \multirow[b]{2}{*}{ Махітит } \\
\hline & & & & & $\begin{array}{l}\text { Lower } \\
\text { Bound }\end{array}$ & Upper Bound & & \\
\hline Man & $\overline{154}$ & $\begin{array}{r}28.9 \\
7\end{array}$ & 1.756 & .142 & 28.69 & 29.25 & 23 & 31 \\
\hline Woman & 193 & $\begin{array}{r}30.9 \\
4\end{array}$ & 2.658 & .191 & 30.57 & 31.32 & 26 & 35 \\
\hline Total & 347 & $\begin{array}{r}30.0 \\
7\end{array}$ & 2.499 & .134 & 29.81 & 30.33 & 23 & 35 \\
\hline
\end{tabular}

Source: Processed Data, 2020

The results of the one-way ANOVA analysis also have a sig value $<0.05$ (Table 11). Referring to the results of a study conducted by Nikki (2016), it is stated that gender can significantly affect a student's learning motivation because there are factors that are inherent in gender, which include perseverance, feeling shy, having enthusiasm in doing a competition, having concentration while studying and also learning routines. The motivation of female students is higher when compared to male students. Therefore, women's financial inclusion learning is better than that of men.

Table 11.

Inova

\section{Inclusion}

\begin{tabular}{lr|r|r|r|r}
\hline & Sum of Squares & \multicolumn{1}{c|}{ Df } & Mean Square & \multicolumn{1}{c}{$F$} & \multicolumn{1}{c}{ Sig. } \\
\hline Between Groups & 332.071 & 1 & 332.071 & 62.663 & .000 \\
\hline Within Groups & 1828.269 & 345 & 5.299 & & \\
\hline Total & 2160.340 & 346 & & & \\
\hline
\end{tabular}

Source: Processed Data, 2020

\subsection{APIC System Capability in Improving Millennial Generation Financial Literacy}

One of the characters identical to the millennial generation is the fondness for using technology and dependence on technology because, from a young age, this generation has been introduced and accustomed to technology, especially smartphones. The soul 
of the millennial generation wants practicality. This generation is always oriented to creating creativity and innovation to make everything simpler and more practical, including in terms of learning. Millennials prefer learning that can be done in any place that makes them feel comfortable. One of the findings from the results of research conducted by the Boston Consulting Group (BCG), the University of Berkley in 2011 regarding the USA millennial generation is that there is an interest in reading activities carried out conventionally, which has decreased at this time due to the selection of selected reading media. Most of it is through technology or even their smartphones.

The use of learning media following the characteristics of the millennial generation will generate interest in that generation to read and try it. The millennial generation's interest in technology will significantly affect the motivation of that generation to learn and understand the material. APIC is a technology-based application system that can produce budget information and realize cash inflows and cash outflows in personal finance. There are also innovative financial learning modules such as animated videos. The APIC-based learning model is following the character and needs of the millennial generation. Therefore, this generation is very interested and motivated to use and understand its contents. With the psychological self-disclosure of students or the millennial generation to understand the financial material packaged in APIC, the meaning to be conveyed through the media becomes easier to convey or more quickly understood by readers who in this study are the millennial generation. Thus, APICbased learning media is very effective in increasing the reader's understanding of finance. Behavioral finance theory also stated that the factors of liking, nature, emotions, and all things in humans as creatures of God who are intellectual and social which decide to take a stance in the financial sector (Sukandani et al., 2019).

The results of this study show results that are in line with the study conducted by Wuryanti dan Kartowagiran (2016), which states that the use of animated videos in the learning model can improve knowledge learners. This finding is also supported by the results of the study conducted by Putri et al. (2019), which concludes that students have an interest in learning about macroeconomic theory by utilizing web-based learning when compared to utilizing conventional media-based learning and this interest 
extensively impacts increasing financial understanding (financial literacy) among students. Teaching materials in the form of a module that has been adapted to suit student characteristics can help increase students' willingness to learn independently, help overcome student learning difficulties, and habituation to technology, which has an impact on increasing student understanding.

\subsection{The Effect of Financial Literacy on Inclusive Management}

The results of the national financial literacy survey conducted by the OJK in 2013 show that financial literacy is closely related to the ability of a person to use a product or service for finance. The survey shows that the high level of financial literacy that a person has will cause the level of use of products and services for financial services to be higher, so it can be said that the higher the level of inclusive financial management carried out. The results of the 2016 survey on financial literacy and financial inclusion found the same thing, where there was a positive relationship between financial literacy and financial inclusion in the conventional or Sharia financial services industry. This is in line with behavioral finance theory, and behavioral finance explains how big the financial phenomenon model can be understood by someone who will influence the final investment decision that is appropriate by considering the return and risk (Pradikasari and Isbanah, 2018).

Ease of use of financial institutions, products, and services following the needs and expertise is supported by the existence of skills in the financial sector which is also accompanied by attitude and wise financial actions. Productive financial decisionmaking can only be realized if the community has a good financial understanding (financial literacy) (Coskuner, 2016). As in the theory of financial literacy, it is stated that the level of knowledge, skills, and confidence will influence attitude and behavior to improve the quality of financial management and the quality of financial decisionmaking in the context of financial literacy to achieve prosperity. This means that people who have been well educated will know the benefits of using banking financial services in helping to improve their welfare. Therefore these people will always take advantage of banking services. Financial education through APIC, which is integrated with a 
choice of financial product services, is a strategy to increase knowledge and awareness of the public about financial products and services.

\section{Conclusions, Implications, and Limitations of The Research}

The conclusions of this study are (a) the developed APIC working system has met the requirements for the validity of materials and media, (b) APIC-based financial learning practices can improve financial literacy, and (c) APIC-based financial literacy has a positive effect on the level of financial inclusion management. The results of this study can be used as a source of information for the government and the community, especially for teachers and lecturers regarding effective financial learning models among the millennial generation. The government can also use the results of this study as a basis to encourage academics and practitioners to help improve financial literacy, which has implications for financial inclusion for the achievement of community welfare. This research also produces APIC-based learning media that can be accessed using a PC or smartphone, practical, effective, and valid, which in the future can be used and utilized by the general public in managing their finances. This study can also be used as reference material, material for theoretical studies, and references in further studies.

The limitation of this study is that it does not review the involvement of family lifestyle, which is also thought to have a dominant influence on children's financial behavior. The child's character reflects the family, so it will be challenging to change the character that has been formed from the culture of the everyday environment of people who have strong emotional closeness. Suggestions for future studies can be to use variables other than those in this study as control variables. Theoretically and based on empirical studies, they have affected finance behavior such as family lifestyle, gender, and education level. 


\section{Reference}

Abubakar, L., \& Handayani, T. (2019). Strengthening Financial Technology Regulation To Empowerment Financial Inclusive. Diponegoro Law Review, 4(2), 274. https://doi.org/10.14710/dilrev.4.2.2019.274-290

Alquraan, T., Alqisie, A., \& Al Shorafa, A. (2016). Do Behavioral Finance Factors Influence Stock Investment Decisions of Individual Investors? (Evidence from Saudi Stock Market). American International Journal of Contemporary Research, 6(3), 159-169. www.aijcrnet.com

Anthony, dan G. (2011). Management Control System: Sistem Pengendalian Manajemen. Buku Dua. Terjemahan Kurniawan Cakrawala. Salemba Empat.

Asri, D. N. (2018). Kenakalan remaja: suatu problematika sosial di era milenial. Seminar Nasional Bimbingan Dan Konseling), 2(1), 2580-216. http://prosiding.unipma.ac.id/index.php/SNBK/index

Awais, M., Fahad Laber, M., Rasheed, N., \& Khursheed, A. (2016). Impact of financial literacy and investment experience on risk tolerance and investment decisions: Empirical evidence from Pakistan. International Journal of Economics and Financial Issues, 6(1), 73-79.

Azizah, Z. F., Kusumaningtyas, A. A., Anugraheni, A. D., \& Sari, D. P. (2018). Validasi preliminary product Fung-Cube pada pembelajaran fungi untuk siswa SMA. Jurnal Bioedukatika, 6(1), 15. https://doi.org/10.26555/bioedukatika.v6i1.7364

Bank Indonesia. (2019). Program Keuangan Inklusif. https://www.bi.go.id/id/perbankan/keu anganinkl usif/program/Contents/defau lt.aspx.\%0A\%0A

Bencsik, A., Juhász, T., \& Horváth-Csikós, G. (2016). Y and Z Generations at Workplaces. Journal of Competitiveness, 6(3), 90-106. https://doi.org/10.7441/joc.2016.03.06

Coskuner, S. (2016). Understanding Factors Affecting Financial satisfaction. The Influence of Financial Behavior, Financial Knowledge and Demographics. Imperial Journal of Interdisciplinary Research (IJIR), Vol. 2(No. 5), pp 377-385.

Fatimah, D. N. (2017). Pengaruh Literasi Keuangan Terhadap Perilaku Keuangan Mahasiswa (Perbandingan Masasiswa Ekonami Dan Non Ekonomi). Fakultas Ekonomi dan Bisnis Universitas Islam Negeri Sunan Kalijaga Yogjakarta.

Kardinal. (2017). Pengaruh Literasi Keuangan Terhadap Penggunaan Produk Keuangan Pada Mahasiswa STIE Multi Data Palembang. Ilmiah STIE MDP, 7(1), 55-64.

Strategi Nasional Literasi Keuangan Indonesia (Revisit 2017), (2018).

Krismasari, E. (2016). Pengembangan Model Matematika Berbasis Pendekatan Kontekstual Pada Materi Aljabar untuk SMP/Mts. Jurnal Pendidikan Matematika, 1, 6-12. 
Nikki, K. (2016). Pengaruh Urutan Kelahiran dan Jenis Kelamin Terhadap Motivasi Belajar Siswa di Smp An-Nur Bululawang. Pakultas Pisikologi Universitas Islam Negeri Maulana Malik Ibrahim Malang.

Noor, Surya Ramadhan, dan Kamaludin, M. D. (2019). Pengaruh Sistem Pengendalian Intern Kas Terhadap Kualitas Laporan Arus Kas Pada Pt Pos Indonesia (Persero) Kp Kuningan 45500. Jurnal Akuntansi, 53(9), 11-20.

Nugroho, A., \& Purwanti, E. Y. (2017). Determinan Inklusi Keuangan di Indonesia. 2, 1-13.

Peraturan Otoritas Jasa Keuangan No. 12, 2018 tentang Penyelenggaraan Layanan Perbankan Digital Oleh Bank Umum, (2018).

Pradikasari, E., \& Isbanah, Y. (2018). Pengaruh Financial Literacy, Illusion of Control, Overconfidence, Risk Tolerance, dan Risk Perception Terhadap Keputusan Investasi Pada Mahasiswa di Kota Surabaya. Jurnal Ilmu Manajemen (JIM), 6(4), 424-434.

PSAK No.2 Tahun 2015 Tentang Laporan Arus Kas, (2015).

Putra, Y. S. (2016). Theoritical Review : Teori Perbedaan Generasi. Among Makarti, 9(18).

Putri, Dian Permana, Anisah Aan, Febianti Yopi Nisa, dan Y. (2019). Analisis Literasi Keuangan Dan Lingkungan Melalui Pembelajaran Berbasis Web Terhadap Perilaku Konsumsi Mahasiswa. Promosi: Jurnal Program Studi Pendidikan Ekonomi, 2, 14 25 .

Safira, N., \& Dewi, A. S. (2019). Peran Modal Sosial Sebagai Mediator Literasi Keuangan Dan Inklusi Keuangan Di Kota Padang. Jurnal Mitra Manajemen, 3(1), 29-43.

Septiyani, A. Dela. (2019). Pengaruh Inklusi Keuangan Terhadap Pendapatan UMKM Di Kota Surakarta. Institut Agama Islam Negeri Surakarta.

Septiarini, D. F. (2013). Akuntansi Keperilakuan, Landasan Akuntansi Keperilakuan Dalam Perspektif Islam. AKRUAL: Jurnal Akuntansi, 5(1), 45. https://doi.org/10.26740/jaj.v5n1.p45-58

Sisputro. (2017). Peran Modal Sosial Sebagai Mediator Literasi Keuangan Dan Inklusi Keuangan Pada Kaum Muda Di Indonesia (Studi Kasus Pada Komunitas Investor Saham Pemula). Jurnal Manajemen Teori Dan Terapan., 1.

Sitohang, M. Y., Siahaan, Y., Astuti, A., \& Silaen, M. F. (2019). Laporan Arus Kas Untuk Menilai Kinerja Keuangan Pada Pt Kalbe Farma, Tbk Yang Terdaftar Di Bursa Efek Indonesia. Financial: Jurnal Akuntansi, 5(2), 22-29. https://doi.org/10.37403/financial.v5i2.107

Sugiyono. (2017). Metode Penelitian Kuantitatif, Kualitatif, dan R\&D. Alfabeta, CV.

Sugiyono. (2018). Metode Penelitian Kuantitatif, Kualitatif, dan R\&D. Alfabeta. 
Syahroh, M. Z., Tarjo, \& Setiawan, A. R. (2019). Minat Investasi Mahasiswa pada Kompetisi Yuk Nabung Saham 2017 di Bursa Efek Indonesia (Pendekatan Mixed Methods). Journal of Research and Application: Accounting and Management, 4(1), 64-77. https://doi.org/10.18382/jraam.v4i1.005

Tafonao, T. (2019). Peran Guru Dalam Menangani Perilaku Menyimpang Di Kalangan Siswa Millenial. Jurnal Akuntansi, 2, 164-179. https://doi.org/10.31220/osf.io/72hq4

Wuryanti, U., \& Kartowagiran, B. (2016). Pengembangan Media Video Animasi Untuk Meningkatkan Motivasi Belajar Dan Karakter Kerja Keras Siswa Sekolah Dasar. Jurnal Pendidikan Karakter, 6(2), 232-245. https://doi.org/10.21831/jpk.v6i2.12055

Yanti, Iko Putri, W. (2019). Pengaruh Inklusi Keuangan Dan Literasi Keuangan Terhadap Kinerja Umkm Di Kecamatan Moyo Utara. Jurnal Manajemen Dan Bisnis, 2(1). https://doi.org/10.37673/jmb.v2i1.305

Yuliani, C. D. (2019). Analisis Dampak Tingkat Pendapatan Dan Perilaku Konsumtif Terhadap Kesejahteraan Keluarga Perspektif Ekonomi Islam. Universitas Islam Negeri Raden Intan. Lampung.

Yuni Sukandani, Siti Istikhoroh, R. B. D. W. (2019). Behavioral Finance Pada Proses Pengambilan Keputusan Investasi. Seminar Nasional Hasil Riset Dan Dan Pengabdian, Ke-II, 150-156. http://snhrp.unipasby.ac.id/

Yuniati, A. (2017). Perilaku Menyimpang dan Tindak Kekerasan Siswa SMP di Kota Pekalongan. Journal of Educational Social Studies, 6(1), 77-83.

Zakiyah, U., Sihombing, G. M. J., Al Aufar, M. Y., Syafira, N., \& Hofifah, S. (2020). Akuntabilitas Pemerintahan Desa Dalam Pengelolaan Anggaran Pembangunan Desa. The Indonesian Journal of Public Administration (IJPA), 6(1), 67-76. https://doi.org/10.52447/ijpa.v6i1.4133 